\title{
EFEKTIVITAS MAKANAN BERBASIS LOKAL TAWAS UT (Ampelocissus Rubuginosa L) TERHADAP STATUS KESEHATAN IBU POST PARTUM DI KOTA PALANGKA RAYA
}

\author{
The Effectiveness of Local-Based Foods of Tawas Ut (Ampelocissus Rubuginosa L) \\ on the Health Status of Post Partum Mothers in Palangka Raya
}

\section{Christine Aden ${ }^{1 *}$ \\ Marselinus Heriteluna ${ }^{2}$}

*Iurusan Keperawatan Poltekkes Kemenkes, Palangka Raya, Kalimantan Tengah, Indonesia

2Jurusan Keperawatan Poltekkes Kemenkes, Palangka Raya, Kalimantan Tengah, Indonesia

*email: christine.aden@ymail.com

\section{Kata Kunci:}

Status Kesehatan

Tawas Ut (Ampelocissus

Rubuginosa L)

Post Partum

\section{Keywords:}

Keyword I

Keyword 2

Keyword 3

Etc

\begin{abstract}
Abstrak
Pemulihan organ reproduksi terutama uterus setelah post partum harus segera terjadi. Uterus harus kembali keukuran normal seperti sebelum hamil. Perawatan untuk memulihkan statu kesehatan ibu pada masa post partum dilakukan masyarakat Dayak dengan menggunakan ramuan herbal Tawas Ut (Ampelocissus Rubuginosa $L$ ). Penelitian ini bertujuan untuk mengetahui status kesehatan ibu post partum dengan pemberian ramuan Tawas Ut sebagai produk pangan Status kesehatan menilai tinggi fundus uteri dan kadar leukosit ibu post partum dengan menggunakan metode quasi eksperimen dengan menggunakan uji $U_{j i}$ independent $t$-test dan $U_{j i}$ t-test berpasangan (paired t-test).

Ditemukan ada perbedaan bermakna rata-rata tinggi fundus uteri antara kelompok intervensi dan kontrol ( $p$ value $0,0 \mathrm{I} 2$ ) dengan perbedaan sebesar sebesar 2,9I, atau ada perbedaan sebesar $6 \mathrm{I}, \mathrm{I} \%$. Hasil uji Paired $t$-tes menunjukkan bahwa ada perbedaan bermakna rata-rata tinggi fundus uteri antara sebelum dan sesudah masa intervensi $(p$ value 0,0005 ) dengan perbedaan tinggi fundus uteri sebesar $10,45 \mathrm{~cm}$ atau perubahan sebesar $84 \%$.

Ini menunjukkan bahwa makanan berbasis lokal Tawas Ut memiliki efektivitas terhadap status kesehatan ibu post partum yaitu mampu menurunkan leukosit sebesar $32 \%$ dan menurunkan tinggi fundus uteri sebesar $84 \%$ ke ukuran normal seperti sebelum hamil.

Penggunaan produk ini disarankan untuk dimanfaatkan sebagai pendamping program pelayanan standar bagi ibu post partum untuk mendukung program pemerintah menurunkan angka kesakitan dan kematian ibu karena masalah post partum.
\end{abstract}

\begin{abstract}
Postpartum recovery of the reproductive organs, especially the uterus, should occur immediately. The uterus should return to its pre-pregnancy size. Treatment to restore maternal health during the postpartum period was carried out by the Dayak community by using the herbal concoction of Tawas Ut (Ampelocissus Rubuginosa L). This study aims to determine the health status of post-partum mothers by administering the Tawas Ut herb as a food product. paired t-test).

It was found that there was a significant difference in the mean fundal height between the intervention and control groups ( $p$-value 0.012 ) with a difference of 2.91 , or there was a difference of $61.1 \%$. The results of the Paired t-test showed that there was a significant difference in the mean uterine fundal height between before and after the intervention period ( $p$-value 0.0005 ) with a difference in uterine fundal height of $10.45 \mathrm{~cm}$ or a change of $84 \%$.

This shows that the local-based food of Tawas Ut has effects on the health status of postpartum mothers, which can reduce leukocytes by $32 \%$ and reduce uterine fundal height by $84 \%$ to normal sizes as before pregnancy.

The use of this product is recommended to be used as a companion to standard service programs for postpartum mothers to support government programs to reduce maternal morbidity and mortality due to postpartum problems.
\end{abstract}

(c) year The Authors. Published by Institute for Research and Community Services Universitas Muhammadiyah Palangkaraya. This is Open Access article under the CC-BY-SA License (http://creativecommons.org/licenses/by-sa/4.0/). DOI: https://doi.org// 0.33084/jsm.vxix.xxx.

\section{PENDAHULUAN}

Post partum adalah masa sesudah persalinan dapat juga disebut masa nifas (puerperium) yaitu masa sesudah persalinan yang diperlukan untuk pulihnya kembali alat kandungan seperti sebelum hamil'. Rahim atau uterus harus berkontraksi untuk berinvolusi kembali keukuran 
normal seperti sebelum hamil dengan berat $60 \mathrm{gram}^{2}$. Selama pemulihan Uterus dan organ reproduksi, tubuh harus terbebas dari infeksi ${ }^{3}$.Infeksi dapat terjadi karena masuknya kuman-kuman ke dalam alat-alat genitalia pada waktu persalinan dan perawatan pada masa post partum $^{2,4,6}$.

Pemulihan masa post partum dipengaruhi oleh faktor internal dan eksternal. Faktor risiko terjadinya infeksi anemia, kurang gizi, kurang perawatan pra natal, kegemukan, status sosial ekonoi rendah, koitus setelah pecah ketuban, dan imunosupresi ${ }^{2}$ Risiko infeksi post partum yang berhubungan dengan peristiwa persalinan adalah persalinan lama, pecah ketuban yang lama, korioamnionitis, pemantauan janin intrauterin, jumlah pemeriksaan dalam vagina touch selama persalinan dan perdarahan ${ }^{2}$. Perbaikan kesehatan maternal merupakan salah satu tujuan Pembangunan Millenium Development Goals (MDGs) 2015. Penurunan angka kematian dijadikan ukuran keberhasilan MDGs yaitu $75 \%$ rasio kematian maternal ${ }^{6}$. Kematian maternal terjadi pada masa nifas dalam waktu 24 jam pertama sebanyak 50\%, sehingga perawatan masa nifas sangat diperlukan ${ }^{4}$. Profil Kesehatan Provinsi Kalimantan Tengah tahun 2015 menyebutkan bahwa kematian ibu disebabkan Kalimantan Tengah disebakan komplikasi dalam persalinan diantaranya kelainan letak/presentasi janin, partus macet/distosia, hipertensi dalam kehamilan (preeklampsia, eklampsia), perdarahan pasca persalinan, infeksi berat/sepsis, kontraksi dini/persalinan premature, dan kehamilan ganda ${ }^{7}$. Berdasarkan Data riset kesehatan dasar Riskesdas tahun 2013 diketahui bahwa 30,4\% rumah tangga di Indonesia memanfaatkan pelayanan kesehatan tradisional ${ }^{8}$. Perawatan tradisional adalah perawatan turun temurun sebagai suatu warisan budaya masyarakat yang diyakini berdampak baik terhadap pemulihan kesehatan.

Perawatan tradisional setelah melahirkan juga dilakukan oleh orang - orang Dayak dalam rangka pemulihan kondisi ibu setelah melahirkan. Perawatan dilakukan dengan menggunakan ramuan herbal Tawas Ut (Ampelocissus Rubuginosa L ). Kearifan lokal masyarakat Dayak di Kalimantan Tengah lebih dari tiga generasi, meyakini bahwa efek Tawas Ut sebagai obat untuk menyembuhkan luka dalam pada ibu post parum. Secara empirisTawas Ut dipercaya memiliki banyak khasiat diantaranya sebagai obat luka luar dan luka dalam setelah melahirkan dan operasi 9 . Masyarakat Dayak mengambil akar Tawas Ut, merebusnya dalam air mendidih dan memberikan air rebusan tersebut untuk diminum ibu sampai merasa pulih.

Tawas Ut sangat mudah ditemukan ditemukan di pasar dengan harga yang terjangkau. Akar Tawas Ut dijual dalam kemasan kering yang sudah di iris keci-kecil. Dari pengamatan peneliti, diketahui bahwa akar Tawas Ut yang sudah kering dapat direbus atau direndam sebagai ramuan yang diminum ibu post partum.

Hasil skrining fitokimia pada penelitian sebelumnya bahwa dalam Tawas Ut terdapat senyawa alkaloid, flavonoid, tanin dan saponin ${ }^{10}$. Penelitian pada tikus menemukan bahwa Tawas Ut berefek sebagai hepatoprotektor"', mampu menyembuhkan luka9 Senyawa alkaloid, flavonoid, tanin, dan saponin memiliki khasiat sebagai antibakteri ${ }^{12,15}$ sebagai antiplasmodium ${ }^{13}$ analgesik $^{14}$ antioksidan, dan antiinflamasi ${ }^{15}$ sebagai adstringen ${ }^{9}$ dan sebagai anti mikroba ${ }^{16}$.

Kearifan lokal penatalaksanaan Tawas Ut sebagai ramuan bagi ibu nifas yang secara empiris dipergunakan masyarakat Dayak belum diteliti efeknya terhadap penurunan tinggi fundus uteri dan anti inflamasi. Penelitian ini akan memberikan mengukur peningkatan status kesehatan ibu post partum yaitu penurunan tinggi fundus uteri dan kadar leukosit darah melalui pemberian ramuan Tawas Ut.

\section{METODOLOGI}

Penelitian ini menggunakan desain quasi experiment dengan pendekatan pre and post test dilanjutkan dengan 
Christine Aden, Marselinus Heriteluna. 2020. The Effectiveness of Local-Based Foods of Tawas Ut (Ampelocissus Rubuginosa L) on the Health Status of Post Partum Mothers in Palangka Raya

post test only design with control grup untuk mengukur efektifitas Tawas Ut. Uji independent t-test untuk mengetahui perbandingan status kesehatan ibu post partum antara kelompok intervensi (kelompok yang diberikan Tawas Ut) dan kelompok kontrol (tidak diberikan Tawas Ut) . Uji t-test berpasangan (paired $t$ test)untuk menilai kadar leukosit yang di intervensi sebelum dan setelahnya.

Populasi dalam penelitian ini adalah seluruh ibu post partum yang melahirkan dengan bidan di Puskemas Kota Palangkaraya dan di Klinik Bidan Swasta selama bulan September sd November 2018.

Kriteria inklusi sampel meliputi lbu post partum normal> 6 jam sampai hari ke 5 post partum,ibu yang bersedia menyusui bayi segera setelah lahir, ibu tidak ada komplikasi penyakit, ibu yang segera ambulasi dini 6 jam post partum, ibu minum obat yang diberikan bidan, bersedia menjadi responden penelitian, bisa membaca dan menulis serta menetap di Palangka Raya dan sekitarnya. Selanjutnya yang menjadi kriteria eksklusi adalah ibu post partum yang mengalami komplikasi dan dirujuk ke rumah sakit.

Besar sampel diukur dengan menggunakan uji hipotesis beda proporsi dua sisi berdasarkan rumus Lemeshow, et al (1997) untuk uji hipotesis beda proporsi dua sisi (two tail). Referensi yang digunakan adalah Artikel Penelitian Pengaruh Ekstrak Daun Kersen Muntingia Calabura L. Terhadap Penyembuhan Luka Perineum ${ }^{35}$ (Iswati \& Marliandiani, 20I7). Berdasarkan perhitungan besar sampel untuk uji hipotesis beda proporsi didapatkan hasil sampel yang diperlukan sebesar 20 sampel untuk kelompok kontrol dan 20 sampel untuk kelompok intervensi, sehingga total sampel 40 ibu postpartum. Ditambah 10\% sehingga sampel menjadi 44 orang.

Proses penetapan Puskesmas yang menjadi kelompok intervensi dan kelompok kontrol adalah dengan melakukan tehnik random sampling.Proses pemilihan subjek penelitian dibantu oleh enam enumerator yaitu
Bidan penolong persalinan yang bertugas di ruang KIA Puskesmas/ BPS.

Penelitian ini dilaksanakan di Kota Palangka Raya dilaksanakan mulai pada September sd November2018. Prosedur permintaan izin kepada responden, baik kelompok kontrol maupun kelompok intervensi, diawali dengan penjelasan tentang tujuan, prosedur dan manfaat penelitian serta harapan peneliti. Kepada responden (kelompok kontrol dan kelompok intervensi) juga dijelaskan bahwa penelitian ini tidak menimbulkan dampak negatif (bukti empiris bahwa ramuan telah dipergunakan lebih 3 generasi) terhadap responden dan dijamin kerahasiaan identitasnya, maupun informasi yang diberikan. Bila responden memahami dan bersedia terlibat dalam penelitian ini, maka kesediaan tersebut didokumentasikan dengan menandatangani lembar persetujuan sebagai responden tetapi disamping itu responden diberi hak menolak terhadap keterlibatan selama penelitian ini. Pada setiap subjek penelitian (kelompok intervensi) diberikan peralatan untuk merebus. Pada akhir penelitian pada responden diberikan pendidikan post partum dan pada bayi diberikan perawatan tali pusat sampai puput.

Alat pengumpulan data yang digunakan dalam penelitian ini terbagi dalam 3 bagian yaitu:

Kuesioner A merupakan instrument pertama yang diisi oleh peneliti untuk mengisi data kadar Flavonoid, Tanin dan Saponin yang ditemukan pada 6 iris Tawas Ut yang direbus dalam 300 ccair mendidih selama 15 menit dan 6 irisTawas Ut yang direndam dalam 300 ccselama I5 menit. Selanjutnya kandungan Flavonoid, Tanin, Saponin yang tertinggilah menjadi bahan intervensi bagi subjek penelitian. Kadar Flavonoid dalam Tawas Ut yang direbus 15 menit dan direndam 15 menit dan diperiksa di Laboratorium Penelitian Dan Pengujian Terpadu Universitas Gajah Mada.

Kuesioner B bagi kelompok kontrol dan kelompok intervensi berupa pertanyaan tentang karakteristik ibu 
hamil yaitu usia, pendidikan, paritas, pekerjaan dan penghasilan.

Kuesioner $\mathbf{C}$ merupakan instrument ketiga yang diisi oleh peneliti berkaitan dengan kadar Leukosit, sebelum dan setelah intervensi pada kelompok intervensi dan pada kelompok kontrol. Dan pengukuran tinggi fundus uteri pada hari pertama dan hari ketujuh sebelum dan setelah intervensi pada kelompok intervensi dan pada kelompok kontrol.

Pengukuran Tinggi Fundus uteri dilakukan sendiri oleh peneliti untuk kesamaan hasil dan pengukuran leukosit dilakukan oleh analis dari Laboratorium Accurate. Analis akan mengambil sampel darah subjek penelitian di tempat penelitian selanjutnya membawa sampel darah tersebut ke Laboratorium Kesehatan Daerah / Laboratorium Accurate Palangka Raya.

Kegiatan pengambilan data di lapangan. Ibu post partum yang berkunjung ke Klinik Bidan Praktik Swasta atau ke rumah selama periode September- November setelah mendapat informasi dari enumerator bahwa ibu post partum sudah memenuhi kriteria inklusi didapatkan sebanyak 59 orang yaitu dari Puskesmas Pahandut 9 orang, Puskesmas Panarung 13 orang, Puskesmas Menteng 5orang, Puskesmas Bukit Hindu 17 orang, Puskesmas Kayon 8 orang dan Puskesmas Kereng 7 orang.

Responden mengisi kuesioner B dan Peneliti melakukan pemeriksaan kesehatan ibu post partum dan mengukur tinggi fundus uteri dengan menggunakan meteran $(\mathrm{cm})$ untuk mengisi kuesioner $\mathrm{C}$. Analis kesehatan melakukan pengambilan darah sesuai protokol. Pengisian kuesioner C dilakukan pada semua ibu post partum kelompok intervensi dan kelompok kontrol pada $\mathrm{HI}$ dan H7.Pengukuran dilakukan di rumah ibu post partum dengan kontrak waktu yang telah disepakati.

Pada ibu post partum kelompok intervensi dijelaskan protokol paket Tawas Ut cara minum selama 7 hari. Peneliti melakukan demonstrasi cara mengolah paket
Tawas Ut dan ibu post partum/ keluarga memperhatikan. I bungkus sediaan kering Tawas Ut di cuci bersih dengan air , direbus dalam panci yang sudah disediakan dengan air sebanyak 300 cc. Direbus selama I5 menit dengan menggunakan api kompor yang sedang. Peneliti mendampingi ibu minum air Tawas Ut. Setelah mendidih, sisa air rebusan diminum satu- dua kali sehari setelah makan pagi, makan siang atau makan malam. Peneliti menjelaskan Setelah minum Tawas Ut ibu bisa merasakan mules-mules / kontraksi dan darah lochea akan keluar lebih banyak. Satu bungkus sediaan Tawas Ut dipakai untuk satu kali merebus. Tawas Ut diminum pada waktu yang sama. Hari ke 7 setelah pengambilan data pengukuran tinggi fundus uteri, dan pengambilan darah, peneliti memberikan pendidikan kesehatan kepada ibu post partum disertai bingkisan ucapan terimakasih.

\section{HASIL DAN PEMBAHASAN}

\section{Analisis Univariat}

a. Hasil Pengujian Kandungan Tawas UtKandungan Tawas Ut diperiksa di Laboratorium Penelitian Dan Pengujian Terpadu Universitas Gajah Mada. Sediaan diterima tanggal 6 Agustus 2018 dan sediaan diuji tanggal 7 Agustus 2018 (terlampir). Dengan hasil pada tabel di bawah ini

Tabel I. Kandungan Air Rebusan Tawas Ut Dari Sediaan Kering

\begin{tabular}{lllll}
\hline No & Parameter & Hasil & Satuan & Metode \\
\hline I & $\begin{array}{l}\text { Tannin Total ekuivalen } \\
\text { Tannin Acid }\end{array}$ & II,55 & $\%$ b/v & $\begin{array}{l}\text { Spektrofot } \\
\text { ometri } \\
\text { UV-vis }\end{array}$ \\
& $\begin{array}{l}\text { Saponin from Quiilaja } \\
\text { bark kuantitatif }\end{array}$ & 0,30 & $\%$ b/v & $\begin{array}{l}\text { Spektrofot } \\
\text { ometri } \\
\text { UV-vis }\end{array}$ \\
& $\begin{array}{l}\text { Total Flavonoid } \\
\text { Ekuivalen Rutin }\end{array}$ & 0,12 & $\%$ b/v & $\begin{array}{l}\text { Spektrofot } \\
\text { ometri } \\
\text { UV-vis }\end{array}$ \\
\hline & & &
\end{tabular}

Tabel 2. Kandungan Air Rendaman Tawas Ut Dari Sediaan Kering

\begin{tabular}{lll}
\hline Parameter Hasil Satuan Metode \\
\hline
\end{tabular}


Christine Aden, Marselinus Heriteluna. 2020. The Effectiveness of Local-Based Foods of Tawas Ut (Ampelocissus Rubuginosa L) on the Health Status of Post Partum Mothers in Palangka Raya

\begin{tabular}{clccl}
\hline $\mathbf{I}$ & $\begin{array}{l}\text { Tannin Total } \\
\text { ekuivalen } \\
\text { Tannin Acid }\end{array}$ & 2,13 & $\% \mathrm{~b} / \mathrm{v}$ & $\begin{array}{l}\text { Spektrofotometri } \\
\text { UV-vis }\end{array}$ \\
$\mathbf{2}$ & $\begin{array}{l}\text { Saponin from } \\
\text { Quiliaja bark } \\
\text { kuantitatif }\end{array}$ & 0,28 & $\% \mathrm{~b} / \mathrm{v}$ & $\begin{array}{l}\text { Spektrofotometri } \\
\text { UV-vis }\end{array}$ \\
$\mathbf{3}$ & $\begin{array}{l}\text { Total Flavonoid } \\
\text { Ekuivalen Rutin }\end{array}$ & 0,05 & $\% \mathrm{~b} / \mathrm{v}$ & $\begin{array}{l}\text { Spektrofotometri } \\
\text { UV-vis }\end{array}$ \\
\hline
\end{tabular}

( sediaan kering 6 iris direndam 15 menit)

Dari Tabel I dan 2 ditemukan hasil air rebusan Tawas Ut selama 15 menit mengandung kadar Tannin, Saponin dan Flavonoid lebih tinggi dari yang direndam.

Hasil uji Tawas Ut yang direbus selama 15 menit dipergunakan untuk perlakuan pada kelompok intervensi

b. Karakteristik Ibu Post Partum

Ibu post partum sebanyak 59 orang dengan karakteristik umur, paritas, pendidikan, pekerjaan, dan penghasilandiuraikan pada Tabel 3 dan Tabel 4 sebagai berikut:

Tabel 3. Distribusi Frekuensi Karakteristik lbu Post Partum di Kota Palangka Raya Tahun 2018

\begin{tabular}{|c|c|c|}
\hline Karakteristik & $N=59$ & $\%$ \\
\hline \multicolumn{3}{|l|}{ Paritas } \\
\hline Primipara & 23 & $39 \%$ \\
\hline Multipara & 26 & $44,1 \%$ \\
\hline Grandepara & 10 & $16,9 \%$ \\
\hline \multicolumn{3}{|l|}{ Pendidikan } \\
\hline Tinggi & 17 & $28,8 \%$ \\
\hline Menengah & 21 & $35,6 \%$ \\
\hline Dasar & 21 & $35,6 \%$ \\
\hline \multicolumn{3}{|l|}{ Pekerjaan } \\
\hline Bekerja & 16 & $27,1 \%$ \\
\hline Tidak Bekerja & 43 & $72,9 \%$ \\
\hline \multicolumn{3}{|l|}{ Penghasilan } \\
\hline $\begin{array}{l}\geq \text { Upah Minimum Rata Rata } \\
\text { Kota Palangka Raya }\end{array}$ & 44 & $74,6 \%$ \\
\hline $\begin{array}{l}\text { < Upah Minimum Rata Rata } \\
\text { Kota Palangka Raya }\end{array}$ & 15 & $25,4 \%$ \\
\hline
\end{tabular}

Analisis univariat dilakukan terhadap 59 sampel ibu post partum, terdiri dari 30 ibu post partum pada kelompok kontrol dan 29 ibu post partum pada kelompok intervensi.

Tabel 4. Gambaran Usia lbu Post Partum di Kota Palangka Raya Tahun 2018

\begin{tabular}{lclcc}
\hline Kelompok & $\mathbf{N}$ & mean & SD & Min - Max \\
\hline $\begin{array}{llll}\text { Intervensi } \\
\text { Tawas Ut }\end{array}$ & 29 & $\begin{array}{l}27,97 \\
\text { tahun }\end{array}$ & 5,6 & $\begin{array}{c}19 \text { tahun - } \\
40 \text { tahun }\end{array}$ \\
Kontrol & 30 & 27,9 tahun & 5,8 & $\begin{array}{c}18 \text { tahun - } \\
43 \text { tahun }\end{array}$ \\
& & & &
\end{tabular}

Tabel 4 Gambaran usia ibu Post Partum di Kota Palangka Raya tahun 2018, rata rata usia ibu pada kelompok intervensi Tawas ut yaitu 27,97 tahun, dengan standar deviasi 5,6, usia terendah 19 tahun dan usia tertinggi 40 tahun. Rata rata usia ibu pada kelompok kontrol yaitu 27,9 tahun, dengan standar deviasi 5,8, usia terendah 18 tahun dan usia tertinggi 43 tahun.

c. Karakteristik Kesehatan Ibu Post Partum

I) Tinggi Fundus Uteri

i) Sebelum masa intervensi

Tabel 5. Gambaran Tinggi Fundus Uteri lbu Post Partum Sebelum Masa Intervensi di Kota Palangka Raya Tahun 2018

\begin{tabular}{ccccc}
\hline Kelompok & $\mathbf{N}$ & mean & SD & Min - Max \\
\hline $\begin{array}{c}\text { Intervensi } \\
\text { Tawas Ut }\end{array}$ & 29 & $13 \mathrm{~cm}$ & 3,64 & $\begin{array}{c}7 \mathrm{~cm}-22 \\
\mathrm{~cm}\end{array}$ \\
Kontrol & 30 & $12,8 \mathrm{~cm}$ & 3,22 & $\begin{array}{c}6 \mathrm{~cm}-19 \\
\mathrm{~cm}\end{array}$ \\
& & & & \\
\hline
\end{tabular}

ii) Setelah masa Intervensi

Tabel 6. Gambaran Tinggi Fundus Uteri lbu Post Partum Setelah Masa Intervensi di Kota Palangka Raya Tahun 2018

\begin{tabular}{|c|c|c|c|c|}
\hline Kelompok & $\mathbf{N}$ & mean & SD & $\begin{array}{l}\text { Min - } \\
\text { Max }\end{array}$ \\
\hline $\begin{array}{l}\text { Intervensi } \\
\text { Tawas Ut }\end{array}$ & 29 & $3,28 \mathrm{~cm}$ & 4,15 & $\begin{array}{l}0 \mathrm{~cm} \mathrm{-} \\
12 \mathrm{~cm}\end{array}$ \\
\hline Kontrol & 30 & $6,33 \mathrm{~cm}$ & 4,33 & $\begin{array}{l}0 \mathrm{~cm}- \\
13 \mathrm{~cm}\end{array}$ \\
\hline
\end{tabular}

2) Kadar Leukosit

i) Sebelum masa intervensi 
Tabel 7 Gambaran Kadar Leukosit lbu Post Partum Sebelum Masa Intervensi di Kota Palangka Raya Tahun 2018

\begin{tabular}{lcccc}
\hline Kelompok & N & mean & SD & Min - Max \\
& & & & \\
\hline Intervensi & 29 & || $155 I, 7 /$ & $374 I, 14$ & $6100 / \mathrm{uL}-$ \\
Tawas Ut & & $\mu \mathrm{L}$ & & $20200 / \mathrm{uL}$ \\
Kontrol & 30 & $\begin{array}{c}\mathrm{III} / 43,3 / \\
\mu \mathrm{L}\end{array}$ & 3289,5 & $4600 / \mathrm{uL}-$ \\
& & & $17000 / \mathrm{uL}$
\end{tabular}

ii) Setelah masa intervensi

Tabel 8. Gambaran Kadar Leukosit lbu Post Partum Setelah Masa Intervensi di Kota Palangka Raya Tahun 2018

\begin{tabular}{ccccc}
\hline Kelompok & N & mean & SD & Min - Max \\
& & & & \\
\hline $\begin{array}{l}\text { Intervensi } \\
\text { Tawas Ut }\end{array}$ & 29 & 7820,6 & 2207,67 & $4100 / \mathrm{uL}-$ \\
& & $/ \mathrm{uL}$ & & $11700 / \mathrm{uL}$ \\
Kontrol & 30 & 8166,6 & 2766,5 & $3700 / \mathrm{uL}-$ \\
& & $/ \mathrm{uL}$ & & $16000 / \mathrm{uL}$
\end{tabular}

4. Uji Normalitas Data

Uji normalitas data menggunakan nilai simpangan baku karena besar sampel per kelompok $<50$. Uji normalitas data berbentuk numerik yaitu usia, tinggi fundus uteri dan kadar leukosit.

Uji normalitas data menggunakan koefisien variasi dengan keputusan uji $<30 \%$ dinyatakan data terdistribusi normal. Data usia dan data tinggi fundus uteri sebelum masa intervensi telah terdistribusi normal dengan masing-masing hasil yaitu koefisien variasi usia sebesar $20,4 \%$ dan koefisien variasi tinggi fundus uteri sebelum masa intervensi sebesar $26,3 \%$. Data tinggi fundus uteri setelah masa intervensi, data kadar leukosit sebelum masa intervensi dan data kadar leukosit setelah masa intervensi tidak terdistribusi normal. Transformasi data dilakukan menggunakan log 10 dan angkar pangkat 2 sehingga uji normalitas data kedua menunjukkan hasil data telah terdistribusi normal.

\section{Analisis Bivariat}

I) Perbedaan rata-rata tinggi fundus uteri sebelumsesudah kelompok intervensi pemberian tawas ut
Tabel 9. Analisis perbedaan rata rata tinggi fundus uteri sebelum dan sesudah intervensi pemberian tawas ut

\begin{tabular}{lcccl}
\hline $\begin{array}{l}\text { Variabel } \\
\text { TFU }\end{array}$ & $\mathbf{n}$ & $\begin{array}{c}\text { Mean } \\
\left(10^{\wedge(\mathrm{x})}\right)\end{array}$ & $\begin{array}{c}\text { Simp Baku } \\
\left(10^{\wedge(\mathrm{x})}\right)\end{array}$ & $\begin{array}{l}\mathbf{P} \\
\text { value }\end{array}$ \\
\hline Sebelum & 29 & $12,3 \mathrm{~cm}$ & 1,32 & 0,0005 \\
Sesudah & 29 & $1,85 \mathrm{~cm}$ & 5,7 & \\
\hline
\end{tabular}

2) Perbedaan Rata-rata tinggi fundus Uteri antara kelompok kontrol dan intervensi

Tabel 10. Analisis Perbedaan rata-rata tinggi fundus uteri antara kelompok kontrol dan intervensi

\begin{tabular}{lcccc}
\hline Variabel & $\mathbf{N}$ & $\begin{array}{c}\text { Mean } \\
\left(10^{\wedge(\mathrm{x})}\right)\end{array}$ & $\begin{array}{c}\text { Simpangan } \\
\left(10^{\wedge(\mathrm{x})}\right)\end{array}$ & Pvalue \\
\hline $\begin{array}{l}\text { Intervensi } \\
\text { Tawas ut }\end{array}$ & 29 & $1,85 \mathrm{~cm}$ & 5,7 & 0,012 \\
Kontrol & 30 & $4,76 \mathrm{~cm}$ & 2,59 & \\
& & & & \\
\hline
\end{tabular}

b. Kadar leukosit

I) Perbedaan rata-rata kadar leukosit sebelum-sesudah kelompok intervensi pemberian tawas ut

Tabel I I. Analisis perbedaan rata rata kadar leukosit sebelum dan sesudah intervensi pemberian tawas ut

\begin{tabular}{lcccc}
\hline $\begin{array}{c}\text { Variabel } \\
\text { Kadar } \\
\text { Leukosit }\end{array}$ & $\mathbf{N}$ & Mean $\left(\mathbf{x}^{2}\right)$ & $\begin{array}{c}\text { Simpangan } \\
\text { Baku }\left(\mathbf{x}^{2}\right)\end{array}$ & P value \\
\hline Sebelum & 29 & $\begin{array}{c}\mid I 272,06 / \\
\mu \mathrm{L}\end{array}$ & 287,6 & 0,0005 \\
Sesudah & 29 & $7661,5 / \mu \mathrm{L}$ & 161,29 & \\
\hline
\end{tabular}

2) Perbedaan Rata-rata kadar leukosit antara kelompok kontrol dan intervensi

Tabel I2. Analisis Perbedaan rata-rata kadar leukosit antara kelompok kontrol dan intervensi

\begin{tabular}{ccccc}
\hline Variabel & $\mathbf{N}$ & Mean $\left(\mathbf{x}^{2}\right)$ & $\begin{array}{c}\text { Simpanga } \\
\mathbf{n} \\
\text { Baku } \\
\left(\mathbf{x}^{2}\right)\end{array}$ & $\begin{array}{c}\mathbf{P} \\
\text { value }\end{array}$ \\
\hline $\begin{array}{cccc}\text { Intervensi } \\
\text { Tawas ut }\end{array}$ & 29 & $7656,25 / \mathrm{uL}$ & 161,291 & \\
\hline
\end{tabular}




\begin{tabular}{lllll}
\hline Kontrol & 30 & $7938,8 \mathrm{I} / \mathrm{uL}$ & $228,0 \mathrm{I}$ & 0,652 \\
\end{tabular}

\section{PEMBAHASAN}

\section{Karakteristik Responden}

Ibu post partum yang bersedia menjadi responden berjumlah 59 orang melampaui target dari perhitungan rumus sebanyak 44 orang. Kondisi ini diduga terjadi karena keinginan ibu segera pulih. Berdasarkan observasi saat kunjungan rumah hampir $90 \%$ ibu post partum setelah melahirkan pulang ke rumah orangtuanya atau orang tua dan keluarga datang menginap di rumah ibu post partum tersebut. Orangtua dan keluarga hadir untuk menolong merawat ibu bayi, keluarga selama proses adaptasi post partum dan sampai kondisi keluarga stabil dengan adanya anggota keluarga yang baru, serta sampai ibu tampak sehat dan meruyan tidak terjadi. Tradisi ini dipertahankan agar ibu post partum tidak sakit.

Berdasarkan data tampak jumlah kelompok intervensi sebelum dan setelah tindakan jumlahnya sama demikian juga kelompok kontrol. Kesediaan kelompok intervensi untuk minum air Tawas Ut dengan patuh karena pengalaman empiris dari orangtua dan sanak keluarga yang ada di rumah, bahwa dahulu pernah minum ramuan yang sama setelah melahirkan. Secara univariat data berdistribusi dengan normal, tabel 4.3 menunjukkan karakteristik ibu post partum dari kelompok kontrol an kelompok intervensi secara total 44,1\%. Pendidikan ibu postpartum 35,6\% berpendidikan dasar dan 35,6\% berpendidikan menengah. Karakteristik pendidikan ibu post partum yang sama banyak antara berpendidikan dasar dan berpendidikan menengah menuntut peneliti menggunakan pendekatan yang berbeda dalam memberikan perawatan post partum dan intervensi Tawas Ut. Ibu post partum yang berpendidikan dasar cenderung sulit untuk menerima penjelasan dan informasi, maka peneliti menggunakan key person yaitu orangtua atau saudara tua untuk memberikan penjelasan manfaat Tawas Ut dan pengalaman saat post partum masa lalu dengan memakai Tawas Ut. Berbeda dengan yang berpendidikan menengah, informasi dan penjelasan yang ilmiah lebih mudah disampaikan serta pengutan dari orang tua.

Lebih dari separuh $74,6 \%$ ibu post partum memiliki penghasilan $\geq$ Upah Minimum Rata-rata. lbu post partum dengan penghasilan lebih dari upah minimum rata, maka memiliki akses lebih untuk memilih melahirkan di fasilitas yang lengkap dengan pelayanan penuh oleh Bidan Praktik Swasta. Bantuan persalinan standar, pengawasan kala IV sampai melewati 6 jam setelah melahirkan menghindarkan ibu post partum dari komplikasi yang terjadi, sampai diijinkan pulang. Ibu post partum lebih dari separuh 71,9\% tidak bekerja, Status sebagai ibu rumah tangga mempunyai keuntungan waktu luang yang lebih fleksibel karena tidak terikat dengan aktivitas pekerjaan dan ibu lebih rileks untuk fokus dalam masa pemulihan post partum.

Rata-rata usia ibu post partum adalah 27 tahun, usia idel untuk melahirkan adalah antara usia 20-35 tahun. Pada usia ini elastisitas dari otot uterus masih baik, tetapi pada ibu yang berusia diatas 35 tahun elastisitas otot uterus berkurang. Usia dibawah 20 tahun elastisitas otot uterus belum maksimal karena organ reproduksi yang belum matang.Usia diatas 35 tahun sering terjadi komplikasi saat sebelum dan sesudah kelahiran karena elastisitas otot uterus telah menurun menyebabkan kontraksi uterus tidak maksimal. Pada ibu yang usianya lebih tua proses involusi uterus banyak dipengaruhi oleh proses penuaan, dimana proses penuaan terjadi peningkatan jumlah lemak. Penurunan elastisitas otot dan penurunan penyerapan lemak, protein serta karbohidrat merupakan hal-hal yang menghambat involusi 
uterus $^{1,2,3,4}$., usia kurang dari 20 tahun elastisitasnya belum maksimal, sedangkan usia diatas 35 tahun sering terjadi komplikasi karena elastisitas otot rahimnya sudah menurun, menyebabkan kontraksi uterus tidak maksimal ${ }^{1,2,3,4}$.

\section{Pengaruh Pemberian Tawas Ut Terhadap} Pemulihan Status Kesehatan Ibu

a. Penurunan Fundus Uteri

Penelitian ini telah menetapkan dalam kriteria inklusi bahwa ibu melahirkan dalam keadaan sehat dan tidak ada komplikasi. Ibu post partum bersedia IMD yang sudah menjadi standar pertolongan persalinan di tempat Puskesmas/ Bidan Praktik Swasta (BPS). Standar BPS bahwa sejak observasi kala IV ibu sudah dianjurkan miring kiri miring kanan, perlahan mulai bangun sesuai toleransi dan sampai enam jam post partum ibu sudah dianjurkan bangun dan mulai berjalan. Standar perawatan di BPS ini tidak menilai kembali pengaruh karakteristik tersebut pada penelitian ini.

Dari Tabel I dan 2 ditemukan hasil air rebusan Tawas Ut selama I 5 menit mengandung kadar Tannin, Saponin dan Flavonoid lebih tinggi dari yang direndam.

Kadar Tannin pada rebusan Tawas Ut I I,55 \% b/v tampak lima kali lebih tinggi dari kadar Tannin yang direndam. Tetapi Kadar Saponin antara yang direbus dan direndam tidak jauh berbeda. Sedangkan kadar flavonoid yang direbus 2x kadar flavonoid yang direndam.

Tabel 9,Hasil uji Paired t-tes menunjukkan bahwa ada perbedaan bermakna rata-rata tinggi fundus uteri antara sebelum dan sesudah masa intervensi ( $p$ value 0,0005).Sejumlah 29 ibu post partum yang dilakukan intervensi pemberian tawas ut, rata-rata tinggi fundus uteri ibu sebelum pemberian tawas ut adalah $12,3 \mathrm{~cm}$ dan rata-rata tinggi fundus uteri setelah pemberian tawas ut adalah $1,85 \mathrm{~cm}$. Perbedaan tinggi fundus uteri antara sebelum dan sesudah intervensi tawas ut adalah sebesar $10,45 \mathrm{~cm}$ atau perubahan sebesar $84 \%$.

Berdasarkan tabel 10 menunjukkan hasil bahwa rata-rata tinggi fundus uteri kelompok intervensi tawas ut yaitu $1,85 \mathrm{~cm}$, pada kelompok kontrol sebesar $4,76 \mathrm{~cm}$. Hasil uji Independent t-tes menunjukkan bahwa ada perbedaan bermakna rata-rata tinggi fundus uteri antara kelompok intervensi dan kontrol ( $p$ value 0,012).Perbedaan tinggi fundus uteri antara kelompok kontrol dan intervensi adalah sebesar 2,9l, atau ada perbedaan sebesar $61,1 \%$.

Teori menyebutkan bahwa pada hari ke sembilan uteri telah masuk dalam rongga panggul',2 $^{1}$. Ibu post partum dalam kriteria inklusi adalah ibu post partum pada hari I sampai dengan hari ke 5. Berarti ibu post partum kelompok kontrol dan kelompok intervensi setelah intervensi hari ke 7 adalah ibu post partum hari ke 7 sampai dengan ibu post partum hari ke 12.

Sejumlah 29 ibu post partum yang dilakukan intervensi pemberian tawas ut, rata-rata tinggi fundus uteri ibu sebelum pemberian tawas ut adalah $12,3 \mathrm{~cm}$ dan rata-rata tinggi fundus uteri setelah pemberian tawas ut adalah $1,85 \mathrm{~cm}$. Penurunan tinggi fundus ini menunjukkan bahwa pada akhir intervensi fundus uteri hari ke 7 sampai hari ke 12 masih teraba I,83 cm diatas simfisis pubis dan belum masuk panggul. Berbeda dengan ibu post partum kelompok kontrol menunjukkan hasil bahwa rata-rata tinggi fundus uteri kelompok kontrol sebesar $4,76 \mathrm{~cm}$ dan kelompok intervensi tawas ut yaitu I,85 cm.Gambaran rata-rata tinggi fundus uteri kelompok kontrol menjelaskan bahwa pada akhir intervensi, fundus uteri hari ke 7 
sampai hari ke 12 masih teraba $4,76 \mathrm{~cm}$ diatas simfisis pubis dan belum masuk panggul. Jika I $\mathrm{cm}$ sama dengan satu jari orang dewasa ${ }^{2}$ maka dalam palpasi tinggi fundus uteri kelompok kontrol teraba sekitar 5 jari diatas simpisis pubis dan masih belum masuk panggul.

Perbedaan tinggi fundus uteri antara kelompok kontrol dan intervensi adalah sebesar 2,91, atau ada perbedaan sebesar 6I,I\%. Hasil uji Paired $t$-tes menunjukkan bahwa ada perbedaan bermakna rata-rata tinggi fundus uteri antara sebelum dan sesudah masa intervensi ( $p$ value 0,0005). Perbedaan tinggi fundus uteri antara sebelum dan sesudah intervensi tawas ut adalah sebesar $10,45 \mathrm{~cm}$ atau perubahan sebesar $84 \%$. Artinya pada ibu post partum yang mendapatkan paket Tawas Ut selama 7 hari akan mengalami penurunan tinggi fundus uteri sebesar 10,45 cm atau mengalami perubahan sebesar $84 \%$.

Merujuk hasil penelitian menunjukkan bahwa gel ekstrak Tawas Ut memiliki aktivitas penyembuhan luka. Gel Ekstrak Tawas Ut yang dioleskan dua kali sehari selama 20 hari pada luka insisi di punggung tikus wistarsepanjang 4 $\mathrm{cm}$ dan kedalaman $\pm 2 \mathrm{~mm}$ mengalami penutupan panjang luka 99,00\% disertai terjadinya reepitelisasi, neokapilerisasi, dan peningkatan kepadatan kolagen pada pengamatan histopatologi'.

Secara fisiologis ibu post partum mengalami proses autolisis dan atropi jaringan pada otot uterus sehingga kembali ke ukuran semula setelah memanjang $10 \mathrm{kali}^{2}$. Adanya intervensi tawas Ut selama 7 hari yang diberikan pada kelompok intervensi memungkinkan memperkuat aktivitas fisiologis yang dialami setiap ibu post partum normal. Tanin dalam Tawas Ut yang direbus memiliki kandungan lima kali lebih besar kandungan Tanin pada
Tawas Ut yang direndam mempu sebagai pengelat untuk menciutkan pori-pori sel uterus ${ }^{10}$ Ketika sel menciut dimungkinkan ukuran sel uterus yang semula hiperplasia menjadi kembali keukuran normal .Secara fisiologis endometrium uterus pada hari pertama post partum memiliki ketebalan 2,5 $\mathrm{mm}$, mempunyai permukaanyang kasar akibat pelepasan desidua, dan selaput janin. Setelahtiga hari mulai rata, sehingga tidak ada pembentukan jaringanparut pada bekas implantasi plasenta. Adanya tanin mempercepat proses fisiologis dengan pemulihan luka dan reepitelisasi neokapilerisasi pada sel endometrium uterus.

Berdasarkan wawancara dengan ibu postpartum dan keluarga yang mendampingi setelah meminum air tawas ut sesuai petunjuk, ibu merasa badan terasa nyaman, tetapi merasa perut agak mules (kontraksi) setelah itu merasakan darah lochea keluar lancar dan lebih banyak dan merasa benjolan pada perut yang semula keras yang disebut Meruyan Batu , lama-kelamaan menjadi lunak dan hilang. Tanda tanda ini katakan keluarga dan ibu post partum sebagai tanda telah sehat dari Meruyan. Meruyan batu sudah hilang karena Tawas Ut. Uterus yang akan berinvolusi kembali ke ukuran normal pada periode post partum, saat di raba atau di palpasi akan teraba keras setinggi pusat (hari pertama setelah melahirkan) dan ditengah ${ }^{1,2,3,4,5}$. Secara fisiologis tinggi fundus turun $\mathrm{I} \mathrm{cm}$ setiap hari sampai hari ke sembilan dan tidak teraba karena sudah masuk dalam rongga panggul ${ }^{1,2,3,4,5}$. Uterus atau rahim yang teraba keras saat palpasi atau dirasakan ibu post partum dan diraba oleh keluarga diistilahkan sebagai Meruyan. 
Secara fisiologis kalau uterus mengalami subinvolusi atau proses involusi yang abnormal, maka uterus teraba lunak dan kontraksi buruk, sakit pada punggung atau nyeri pada pelvik yang konsisten, perdarahan pervaginam abnormal seperti perdarahan segar, lochea rubra banyak, peristen dan berbau busuk. Keadaan ini membahayakan kondisi ibu karena terjadi perdarahan post partum $3,4,5$

Hasil penelitian yang dilakukan pada mencit disebutkan bahwa efek Tawas Ut sebagai hepatoprotetor bahwa terjadi peningkatan SGOT dan SGPT yang bermakna."

Dalam Tawas Ut terdapat kandungan flavonoid, tanin, soponin, dan tidak ditemukan steroid dan alkaloid. Kandungan flavonoid yang tinggi pada tawas ut dapat meningkatkan resistensi dan mengurangi permeabilitas kapiler darah yang mengganggu transportasi metabolisme. Berarti semakin tinggi kandungan flavonoid memungkinkan terjadinya peningkatan enzim dalam darah.

Pada penelitian ini ibu post partum minum air Tawas Ut yang direbus selama 15 menit. Ditemukan kadar flavonoid yang direbus $2 x$ kadar flavonoid yang direndam.

lbu post partum semakin merasa badannya menjadi sehat, secara langsung flavonoid menyehatkan tubuh. SGOT (serum glutamic pyvuric transaminase) dan SGPT (serum glutamic oxaloacetic transaminase) adalah merupakan enzim hati, jika dikeluarkan dalam jumlah normal akan menunjukkan bahwa hari berfungsi dengan baik. Hati pada tubuh berfungsi menghancurkan sel darah merah yang sudah berumur tua, membersihkan darah dari racun atau senyawa berbahaya, mengurai hormon dalam tubuh, mengubah beberapa zat dalam tubuh untuk dikeluarkan dari tubuh, menyimpan energi, memproduksi protein, albumin, kolestrol dan trigeliserida, memproduksi cairan empedu untuk membantu mencerna makanan $3,4,5$

Semua ibu post partum dari kelompok intervensi dan kelompok kontrol memberikan ASI pada bayinya, jadi efek oksitosin untuk merangsang kontraksi uterus dialami oleh semua ibu post partum. Semua ibu post partum segera melakukan ambulasi dini dan mobilisasi serta tidak dianjurkan untuk pantang makanan agar nutrisi tetap terjaga. Hanya ibu post partum yang diintervensi mengaku setelah minum Tawas Ut merasakan perut lebih sering mules dan merasakan Lochea lebih banyak keluar.

b. Kadar Leukosit

Tampak pada Tabel II, dijelaskan bahwa sejumlah 29 ibu yang dilakukan intervensi pemberian tawas ut, rata-rata kadar leukosit ibu sebelum pemberian

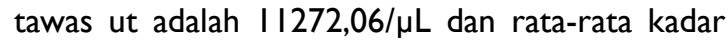
leukosit setelah pemberian tawas ut adalah

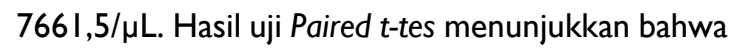
ada perbedaan bermakna rata-rata kadar leukosit antara sebelum dan sesudah masa intervensi ( $p$ value 0,0005). Perbedaan kadar leukosit antara sebelum dan sesudah intervensi yaitu sebesar $3610,56 / \mu \mathrm{L}$ atau sekitar 32\% perubahan kadar leukosit dari leukosit awal.

Berbeda pada tabel 12 tampak hasil uji Independent t-tes menunjukkan bahwa tidak ada perbedaan bermakna rata-rata kadar leukosit antara kelompok intervensi dan kontrol ( $p$ value 0,652).

Berdasarkan gambaran rata-rata leukosit kelompok intervensi dan kelompok kontrol sebelum intervensi tampak meningkat sedikit dari nilai normal. Proses mekanisme pertahanan tubuh seperti luka pada uterus akibat persalinan menyebabkan leukositosis, yang ditandai dengan adalah peningkatan jumlah sel darah putih (leukosit) melebihi kadar normal di dalam darah yaitu 
Christine Aden, Marselinus Heriteluna. 2020. The Effectiveness of Local-Based Foods of Tawas Ut (Ampelocissus Rubuginosa L) on the Health Status of Post Partum Mothers in Palangka Raya

$11.000 / \mathrm{mm}^{3}$ dan akan meningkat sebanyak 15.000/mm3. Tampak kadar leukosit pada kelompok intervensi terendah $6100 / \mu \mathrm{L}$ dan kadar leukosit tertinggi $20200 / \mu \mathrm{L}$. Sedangkan pada kelompok kontrol kadar leukosit terendah terendah $4600 / \mu \mathrm{L}$ dan kadar leukosit tertinggi $17000 / \mu \mathrm{L}$.Jumlah leukosit akantetap tinggi selama beberapa hari pertama masa post partum. Leukosit yang meningkatmenunjukkan suatu respon fisiologis untuk melindungi tubuh darimikroorganisme ${ }^{5}$ Sebelum intervensi tampak leukosit tertinggi kelompok intervensi adalah 20200 / $\mu \mathrm{L}$ dan leukosit tertinggi kelompok intervensi adalah tertinggi $17000 / \mu \mathrm{L}$.

Peningkatan kadar leukosit seringterjadi akibat adanya infeksi, sebagai respon terhadap agen infeksius ${ }^{6}$. Hal ini ditandai dengan meningkatnya suhu badan ibu post partum selama 24 jam pertama setelah melahirkan ${ }^{1,2,3,4}$. Respon infeksi ini tidak terjadi dan tidak dikeluhkan oleh ibu post partum, karena semua ibu post partum yang melahirkan dalam keadaan sehat dengan stamina yang baik, melahirkan per vaginam tanpa tindakan yang spesifik dengan alat, bayi lahir langsung menangis, ibu melahirkan dengan perdarahan normal dan segera ambulasi dini setelah melalui kala IV dengan normal. Merujuk sterilitas dalam proses persalinan juga akan sangat berpengaruh terhadap kontaminasi bakteri yang dapat meningkatkan kejadian leukositosis/ infeksi pada masanifas, maka pencegahan infeksi dilakukan bidan dengan menggunakan standar asuhan persalinan normal (APN) saat menolong persalinan.Semua ibu post partum diberikan obat antibiotika dan vitamin untuk mengatasi peradangan.

Semua ibu post partum sudah mendapatkan perawatan dan pengobatan standar untuk pencegahan reaksi radang. Tampak hasil yang bermakna pada 29 ibu post partum yang mendapatkan intervensi Tawas Ut rata-rata kadar leukosit ibu sebelum pemberian tawas ut adalah

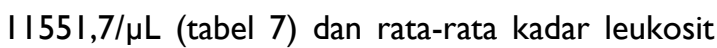
setelah pemberian tawas ut adalah 7820,6/ $\mu \mathrm{L}$ (tabel 8) dengan kadar tertinggi kadar II.700 / $\mu \mathrm{L}$. Sedangkan pada kelompok kontrol rata-rata kadar leukosit sebelum intervensi adalah I I |43,3 / $\mu \mathrm{L}$ dan setelah selesai intervensi lihat Tabel 4.8 rata-rata kadar leukosit kelompok kontrol adalah 8166,6/uL, tetapi kadar tertinggi leukosit adalah $16000 / u L$. Berdasarkan data tersebut tampak kelompok intervensi yang menyelesaikan paket tawas ut sampai hari ke 7 kadar leukosit tertinggi hampir normal dengan nilai II.700/ $\mu \mathrm{L}$. Berbeda dengan kelompok kontrol tanpa dukungan paket Tawas Ut pada hari ke 7 masih ada ibu post partum mengalami leukositosis dengan kadar leukosit $16000 / \mathrm{uL}$.

Walaupun berdasarkan tabel I2dan hasil uji Independent t-tes menunjukkan bahwa tidak ada perbedaan bermakna rata-rata kadar leukosit antara kelompok intervensi dan kontrol ( $p$ value 0,652). Tetapi Tabel I Imenjelaskan hasil uji Paired t-tes bahwa ada perbedaan bermakna rata-rata kadar leukosit antara sebelum dan sesudah masa intervensi ( $p$ value 0,0005).Bahwa dampak paket Tawas Ut pada 29 ibu post partum sebelum dan sesudah intervensi menunjukkan perbedaan kadar leukosit antara sebelum dan sesudah intervensi yaitu sebesar 3610,56/ $/ \mu \mathrm{L}$ atau sekitar 32\% perubahan kadar leukosit dari leukosit awal.Artinya hasil ini menunjukkan bahwa dengan penambahan paket Tawas Ut selama 7 hari pada ibu post partum maka kadar leukosit dari leukosit awal akan mengalami perubahan sekitar 32\%.

Kandungan Tawas Ut selain Tanin adalah Flavonoid dan Saponin. Ibu post partum kelompok kontrol yang meminum Tawas Ut selain mendapatkan efek Tanin juga efek Flavonoid dan Saponin. Kadar leukosit yang menjadi normal setelah hari ke 7 dan atau kadar leukosit mengalami perubahan sebanyak 
32\%. Diketahui bahwa Fungsi Flavonoid yaitu melindungi struktur sel, meningkatkan efektivitas vitamin $C$, anti inflamasi dan sebagai anti biotika ${ }^{30}$ Selain itu efek dari Flavonoid dan mampu mencegah leukositosis,pembuluh darah kapiler menjadi kuat, menurunkan permebilitas dan fragilitas pembuluh darah.Flavonoid memiliki khasiat sebagai antioksidan, antibakteri, antiinflamasi ${ }^{15}$. Demikian juga saponin memiliki aktivitas yang luas seperti antibakteri dan antifungi ${ }^{9,12,14,15,16}$. Sejalan hasil penelitian bahwa saponin memiliki kemampuan menghambat pertumbuhan bakteri ${ }^{36}$ Saponin dapat meningkatkan proses penyembuhan luka dengan meningkatkan produksi kolagen serta mempercepat proses epitelisasi. Saponin mampu mendorong pertumbuhan sel epitel yang bertugas untuk melindungi luka dari bakteri dan kehilangan cairan..

\section{KESIMPULAN}

I. Ada perbedaan rata rata tinggi fundus uteri antara sebelum dan sesudah intervensi tawas ut

2. Ada perbedaan rata rata tinggi fundus uteri antara kelompok kontrol dan kelompok intervensi tawas ut

3. Ada perbedaan rata rata kadar leukosit antara sebelum dan sesudah intervensi tawas ut

4. Tidak ada perbedaan rata rata kadar leukosit antara kelompok kontrol dan kelompok intervensi tawas ut.

\section{REFERENSI}

I. Bobak, M.I., Lodermik, L.D., \& Jensen, D.M. 2010. Buku ajar keperawatan maternitas. Alih bahasa Maria A.Wijayarini \& Peter I.Anugerah. Jakarta :EGC

2. Reede rdkk, 201l. Keperawatan Maternitas Kesehatan Wanita, Bayi dan Anak ed 18, EGC,

3. Winjosastro, Wiknjosastro, H., et al. 2002. IImu Kebidanan. Jakarta. Yayasan Bina Pustaka.

4. Prawirohardjo, 2010. Ilmu Kebidanan ed.4.-Jakarta : Bina Pustaka Sarwono Prawirohardjo,
5. Saifuddin, Abdul Bari. 2006. Buku Panduan Praktis Pelayanan Kesehatan. Maternal dan Neonatal, Jakarta Yayasan Bina Sarwono Prawirohardjo.

6. Adriansz. 2008. Kesehatan Reproduksi .Jakarta : JNPK-KR/POGI

7. Propil Kesehatan Kalimantan Tengah Tahun 2015

8. Aditama, T.Y., Badan Litbangkes RI 2014

9. Khoerul Anwar, Dewita Fitri Widodo. Aktivitas Gel Ekstrak Etanol Umbi Akar Tawas Ut ( Ampelocissus Rubiginosa L ) Terhadap Penyembuhan Luka Insisi Pada Tikus Wistar ; Tradisional Medicine Journal , 23 (I) p 30-39, Januari -April 2018

https://jurnal.ugm.ac.id/TradMedj/article/view/2906 $\underline{3}$

10. Nisbullah, 2013, Formulasi dan evaluasi sediaan salep ekstrak etanol akar tawas ut (Ampelocissus rubiginosa lauterb) dengan variasi konsentrasi vaselin album dan cera alba, skripsi program studi farmasi, universitas lambung mangkurat https://jurnal.ugm.ac.id/TradMedj/article/view/2906 $\underline{3}$

II. Astuti et all, 2016 Astuti. K.I., Anwar, K \& Biworo. A.,2016, Uji Aktivitas Infus Akar Tawas Ut (ampelocissus rubinigosa $L$ ) sebagai Hepatoprotektor Terhadap Mencit Putih Jantan Balb/C Yang Diinduksi Karbon Tetraklorida (Ccl4) Jurnal Pharmascemce, 3, 57-63. https://www.researchgate.net/publication/3126254 52 Uji_Aktivitas_Infusa_Akar_Tawas_Ut_Ampel ocissus rubiginosa_L_Sebagai Hepatoprotektor Terhadap Mencit Putih Jantan BalbC Yang Diin duksi Karbon Tetraklorida $\mathrm{CCl} 4$

12. Khaharap,E., 2012. Uji Bakteri Ekstrak Etanol Akar Tawas Ut (Ampelocissus Rubinigosa L) Pada Eschericia ColiDan Staphylococcus Aureus Secara In Vitro, Skripsi, Program Studi Farmasi, Universitas Lambung Mangkurat https://jurnal.ugm.ac.id/TradMed//article/view/2906 $\underline{3}$

13. Arnida, Wahyono, Mustofa Dan Asmahsusidarti,R., 2015, In Vitro Antiplasmodial Activity Of Etanol Extracts Of Borneo Medicinal Plants (Hydrolea Spinosa, Ampelocissus Rubiginosa, Uraria Crinite, Angiopteri Sevecta) International Journal Of Pharmacy And Pharmaceutical Sciences,7,72-75 https://innovareacademics.in/journals/index.php/ijp ps/article/view/4842

14. Farauk, L.,A. Laroubi, R.Aboufatima, A,Benharref \&A.Chatt, 2008, Evaluation Of The Analgesic Effect Of Alkaloid Extract Of Peganum Harmala L,: Possible Mechanisms Involved, Journal Of Ethnopharmacology, II5, 449-454 https://www.sciencedirect.com/science/article/abs/ pii/S0378874107005466

I5. Arum, Y.P., Supartono Dan Sudarmini 20I2, Isolasi Dan Uji Daya Anti Mikroba Ektrak Daun Kersen (Muntingia Calabura),Jurnal Mipa Unnes, 35, I65174 
https://journal.unnes.ac.id/nju/index.php//M/article/ view/2626

16. Nayak , B.S.,S.Sandiford, Dan A.Maxwell, 2009, Evaluation Of The Wound Healing Activity Of Ethanolic Extract Of Morinda Citrifolia L.Leaf, Evidence Based Complement Alternative Medicine, $\quad$ 6, $35 \mathrm{I}-356$ https://www.ncbi.nlm.nih.gov/pmc/articles/PMC27 22214l

17. A Normal Pattern Of Uterine Involusion Using S-FD In Primiparous Women And The Prevalence Of Uterine Subinvolution Journal Of Medical Sciences., 6(6): 10 I I1014,2006. https://scialert.net/fulltext/?doi=ims.2006.1011.101 4

18. Prawirohardjo S. Ilmu Kebidanan.Edisi Kedua. Jakarta: Bina Pustaka. 2008

19. Wiknjosastro H. 20I0. Ilmu Kebidanan. Yayasan Bina Pustaka Sarwono Prawiroharjo. Jakarta. 2005 8. Prawirohardjo S. Ilmu Kebidanan.Edisi Kedua. Jakarta: Bina Pustaka. 2008 9. Waryana. Gizi Reproduksi. Cetakan I. Yogyakarta: Pustaka Rihama.

20. Siti Rofiah, Bekti Yuniyanti, Adi Isworo,FaktoFaktor Yang Berhubungan Dengan Penurunan Tinggi Fundus Uteri Pada Ibu Nifas 6 Jam Post Partum , Jurnal Riset Kesehata, Vol 4 No 2, Mei 2015

https://scholar.google.co.id/citations?user=R9vhd QIAAAAJ\&hl=id

21. Dede Mahdiyah ,Hubungan Mobilisasi Dini Dengan Penurunan Fundus Uteri Akademi Kebidanan Sari Mulya Banjarmasin https://scholar.google.co.id/citations?user=rv0bMd MAAAAJ\&hl=en

22. Waryana. 20I0. Gizi Reproduksi. Cetakan I. Yogyakarta: Pustaka Rihama.

23. Chie Shitami, Kazuko Takenaka, Early Puerperium Involution Of The Uterus After Caesarian Section : Basic Data For Use In An Assessment Indekx) J.Jpn.Acad.Midwif, Vol.30 No.2 .333-34I,2016

24. A Normal Pattern Of Uterine Involusion Using SFD In Primiparous Women And The Prevalence Of Uterine Subinvolution Journal Of Medical Sciences., 6(6): I0I I-I0|4,2006.) https://scialert.net/fulltext/?doi=jms.2006.1011.101 $\underline{4}$

25. Mariah Ulfah, Maya Safitri, 2016. Perbedaan Penurunan Tinggi Fundus Uteri Masa Nifas Sebelum Dan Sesudah Latihan Otot Perut Dan Otot Dasar Panggul, Temu Ilmiah Hasil Penelitian Dan Pengabdian Masyarakat https://jurnal.unimus.ac.id/index.php/psn I2012010/ article/view/2098

26. Karunita Ika Astutil, Khoerul Anwar, Agung Biwor,Uji Aktivitas Infusa Akar Tawas Ut (Ampelocissus rubiginosa L.) Sebagai HepatoprotektorTerhadap Mencit Putih Jantan Balb/C YangDiinduksi Karbon Tetraklorida (CCl4) https://www.semanticscholar.org/paper/UjiAktivita
s-Infusa-Akar-Tawas-Ut-(Ampelocissus-AstutiAnwar/a82408be4c0bb8e6feb03486e24l ca77688f $\underline{7317}$

27. Nurhalifah 2009. Karakterisasi Simplisia, Skrining, Fitokimia Dan Isolasi Senyawa Flavonoida Dari Daun Tanaman Ekor Naga (Rhaphidophora Pinnata Schott). Fakultas Farmasi Universitas Sumatera Utara .Skripsi http://repository.usu.ac.id/handle//23456789//703 $\underline{5}$

28. Margaretha, Ferandez, Wiratmini,Ni Ermayanti,Pengaruh pemberian ekstrak daun ekor naga (Rhaphidophora pinnata Schott) terhadap perkembangan uterus mencit (Mus Musculus) Betina yang telah diovariektomi, Jurnal Biologi Udayana, https://ojs.unud.ac.id/index.php/BIO/article/view/2 $\underline{1258}$

29. Shafa Noer et all, Penetapan Kadar Senyawa Fitokimia Tanin, Saponin, Dan Flavonoid sebagai Kuersetin) Pada Ekstrak Daun Inggu ( Ruta Angustifolia) Eksakta: Jurnal Ilmu-Ilmu MIPA P. ISSN: I4 I I-I047 E. ISSN: 2503-2364

30. Pendidikan Biologi, Fakultas Teknik Dan MIPA Universitas Indraprasta PGRI Jakarta Shafa_Noer@Yahoo.Co.Id https://www.researchgate.net/publication/3226383 07 Penetapan_Kadar Senyawa Fitokimia Tanin Saponin_dan_Flavonoid_sebagai_Kuersetin_Pada Ekstrak_Daun_Inggu_Ruta_angustifolia_L

31. Ahmad Baequny, Supriyo, Sri Hidayati Efektivitas Minum Jamu (Ramuan Daun Katuk, Kunyit, Lempuyangan, Asem Jawa) Terhadap Produksi Asi Pada Ibu Nifas ,Program Studi Keperawatan Poltekkes Kemenkes Semarang Email:Baequny@Gmail.ComHttp://Www.Jurnal.Un ikal.Ac.Id/Index.Php/Pena/Article/Viewfile/403/36I https://jurnal.unikal.ac.id/index.php/pena/article/vie w/403

32. Yunita Fitrianti dan Tri Juni Angkasawati ,Pengobatan Tradisional Gayo Untuk Ibu Nifas (Gayo's Traditional Medication For Puerperal Mother)Jurnal Pharmascience, Vol .03, No.02, Oktober 2016, hal: 57 - 63 https://media.neliti.com/media/publications/20935ID-gayos-traditional-medication-for-puerperalmother.pdf

33. Sabirin , I.P.R., Maskoe,A.M. \& Hernowo, B.S.,20I3, Peran Ekstrak Etanol Topikal daun Mengkudu ( Morinda Citrifolia L ) pada penyembuhan luka di tinjau dari imunoekspresi CD34 dan kolagen pada tikus galur wistar, Majalah Kedokteran Bandung, 45,

226-233 http://journal.fk.unpad.ac.id/index.php/mkb/article/ view/169

34. Iswati \& Marliandiani, 2017, Pengaruh Ekstrak Daun Kersen Muntingia Calabura L. Terhadap Penyembuhan Luka Perineum,

35. Maatalah et all, Antimicrobial activity of the alkaloid and saponin extracts of anabasis articulata,E3 Journal 
of Biotechnology and Pharmaceutical Research Vol. E3 Journal of Biotechnology and Pharmaceutical Research Vol. 3(3), Pp. 54-57, May 2012 , https://www.semanticscholar.org/paper/Antimicro bial-activity-of-the-alkaloids-and-saponin-MaatalahBouzidi/4ffa4532c96fe5b3cc6e9680fb310e6fd803c 7a2 